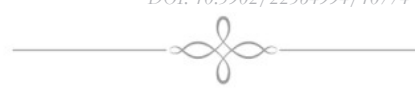

\title{
O ensino de Geografia versus leitura de imagens: resgate e valorização da disciplina pela "alfabetização do olhar"
}

Osvaldo Girão*

Surama Ramos Lima**
Resumo: Este artigo trata da utilização de imagens em sala de aula e tem por objetivo demonstrar os resultados quantitativos obtidos junto a alunos do Ensino Médio e Normal Médio (Magistério) da Escola João Cavalcanti Petribú, localizada na cidade de Carpina/PE, que apontaram ser eficiente e prazeroso aprender Geografia fazendo uso de imagens diversas. Pesquisa realizada com esses alunos ratificaram o poder da imagem na sociedade globalizada e sua contribuição para o processo de ensino-aprendizagem.

\section{The teaching of Geography versus reading images: rescue and recovery of discipline for "look of literacy"}

* Departamento de História, área Geografia Física e Ensino da Geografia- Universidade Federal Rural de Pernanbuco

** Escola João Cavancanti Petribú, Secretaria de Educação do estado de Pernambuco - Professora de Geografia do Ensino Médio

Palavras-chave:

Uso de Imagens; Processo de Ensino-aprendizagem; Ensino de Geografia.

Key-Words:

Use of Images; Teachinglearning Process; Teaching Geography. 


\section{Introdução}

Ao longo de sua história o homem utilizou diversos recursos para comunicar-se e imprimir na paisagem sua marca. Desenhou em cavernas, pintou e registrou em rochas e cavernas seus anseios e sua cultura. Registros que superaram o tempo e que hoje são analisados para contar a História da humanidade.

Por um longo período as imagens fizeram parte do cotidiano das pessoas. No entanto, a evolução da sociedade e a busca incessante por novas formas de comunicação permitiram que o homem dotado de Inteligência e capacidades múltiplas, descobrisse a escrita e revolucionasse o convívio em sociedade, utilizando-a em vários momentos como instrumento de dominação e segregação social. A escrita desenvolveu-se e ganhou destaque, sobretudo, com a sociedade moderna dominada pela burguesia e amparada pelo capitalismo.

Todavia, a Revolução Técnico-Científica, e a consequente evolução dos meios de comunicação, aos poucos foram transformando a sociedade e o modo como os indivíduos se relacionam. A escrita que era tida como recurso incontestável e único instrumento capaz de registrar os fatos históricos e o cotidiano das pessoas, na atualidade, tem perdido espaço para a utilização das imagens. Compará-las, questioná-las, decodificá-las e a partir daí, construir conceitos é a função da escola no Século XXI.

A sociedade contemporânea é multicultural e de múltiplas linguagens, portanto, cabe a escola e, em especial a disciplina Geografia, preparar os alunos para lidar com essas novas linguagens e torná-los aptos a exercerem sua cidadania de fato, utilizando para isso, uma nova forma de alfabetização que exige outro sentido, "a alfabetização do olhar".

Debruçar-se sobre as imagens e decodificá-las é uma tarefa agradável e prazerosa, tendo em vista que a imagem aproxima o indivíduo da mensagem permitindo decodificar com mais facilidade o que se quer representar, desperta emoções e possibilita um entendimento mais rápido do que lhe é proposto, favorecendo plenamente ao processo de ensino-aprendizagem.

\section{A Imagem como leitura de mundo e sua evolução}

A prática da utilização de imagens remonta aos nossos antepassados. Desde o seu surgimento o homem tem deixado marcas impressas que representam suas vidas. Comunicarse sempre foi uma necessidade e um anseio da espécie humana. Por toda parte no mundo o homem deixou vestígios de sua imaginação e vivência.

Conforme atesta Manguel (2009), nossas primeiras imagens são simples linhas e cores borradas, que antecederam figuras de antílopes e de mamutes e, posteriormente, nossa palma das mãos estampadas nas paredes de cavernas, assinalando nossa presença.

Desde a pré-história o homem procura de diversas maneiras formas de comunicação e entendimento de mundo. Os registros iconográficos sempre estiveram ligados à evolução e a história da humanidade, as pinturas rupestres demonstram bem esse desejo de retratar, por exemplo, hábitos cotidianos e perpetuar sua cultura. Desenhando e analisando a natureza o homem aprendeu a desenvolver outros sentidos e, para Ginzburg, 1987, (apud COSTA, 2005, p.13) "a escrita teria surgido do uso de um dos nossos mais antigos dons - a observação".

As imagens fazem parte da vida e são extremamente importantes para a compreensão do mundo, permitindo a análise dos fatos que cotidianamente nos rodeiam. "Sem a imagem a cotidianidade seria impossível. Mesmo quando não temos uma fotografia para cada situação, o imaginário cria a imagem em nós e para nós" (MARTINS, 2009, p.43).

Geografia Ensino \& Pesquisa, v. 17, n. 2 p. $88-106$, maio./ago. 2013

Girão, O.; Lima, S. R. 
Podemos usar a imaginação para antecipar os movimentos reais. Podemos fazer as coisas na mente antes de fazê-las com as mãos (...). Portanto, ao mesmo tempo em que construímos um conceito, estamos construindo uma imagem dele (PONTUSCHKA e OLIVEIRA 2009, p.172 e 201).

Amplamente utilizada por nossos antepassados, que a desenvolveram observando a natureza, as imagens aos poucos foram perdendo espaço para a escrita. Com o passar do tempo os signos utilizados para representar os elementos que compunham o espaço foram ficando insuficientes para a gama de coisas que se queria demonstrar. Os desenhos destinavam-se a comunicar mensagens, e muitos deles constituíram o que se chamou de precursores da escrita.

As primeiras tentativas de se criar sistemas de escrita, aconteceram a aproximadamente 4.000 AC. Com o passar do tempo, surgem os primeiros alfabetos aprimorados ao longo dos anos por várias civilizações. A utilização do ideograma e a descoberta do alfabeto revolucionaram a forma de pensar e ampliaram os horizontes para a comunicação humana.

A escrita acompanha lentamente a evolução do homem. Com o passar dos séculos cada povo sente a necessidade de registrar com clareza suas ideias e expressões mais significativas. Cada cultura cria uma simbologia e forma de registro própria. A escrita passou a nortear a vida em sociedade possibilitando ao homem um maior desenvolvimento intelectual, pois, esta passou a fornecer-lhe informações capazes de ampliar sua capacidade cognitiva.

Ao inventar a escrita, o homem afastou-se ainda mais do mundo concreto quando, efectivamente, pretendia aproximar-se dele. A escrita surge de um passo aquém das imagens e não um passo em direção ao mundo. Os textos não significam um mundo directamente, mas através de imagens rasgadas. Decifrar textos é descobrir as imagens significadas pelos conceitos. A função dos textos é explicar as imagens (FLUSSER, 1998, p. 30).

O surgimento da escrita de certa forma contribuiu para distanciar o homem do mundo real, tendo em vista que ao ler um texto o indivíduo buscaria na memória imagens que fossem capazes de ilustrá-los e, por conseguinte, transformar os textos escritos mais acessíveis e menos rebuscados. Ou seja, mesmo utilizando a escrita como forma de comunicação na sociedade, os homens tendem a recorrer às imagens para conseguir compreendê-la. Afinal, a escrita, é um instrumento de difícil manuseio, haja vista que necessita de um amplo conhecimento de códigos ortográficos, concordância, sintaxe, entre outros, o que dificulta o seu entendimento e a sua utilização. Entendê-la e dominá-la é um processo demorado e que requer esforço, dedicação e prática repetitiva.

Com a escrita as relações sociais transformaram-se drasticamente e a escrita passou a ser utilizada como símbolo de nobreza e ascensão social. Os que dominavam a arte de escrever detinham grande poder e gozavam de privilégios com os soberanos. Afinal, a escrita funcionava como uma espécie de "trampolim" para se alcançar o topo da cadeia hierárquica.

Para a sociedade moderna a escrita constitui-se na sua linguagem por excelência, com a qual se expressa e se legitima, fazendo do documento escrito o alicerce dos direitos e obrigações, sendo o domínio da escrita cada vez mais um importante elemento de distinção social, e a alfabetização um salvo-conduto para a inserção no mercado de trabalho e, por conseguinte, à mobilidade social (COSTA, 2005).

Numa sociedade elitista, que prezava pela escrita, era necessário o surgimento de uma

Geografia Ensino \& Pesquisa, v. 17, n. 2 p. $88-106$, maio./ago. 2013

O ensino de geografia versus leitura de imagens: resgate e valorização da disciplina pela "alfabetização do olhar" instituição que fosse capaz de capacitar as pessoas para lidar com tais avanços, haja vista que, desvendar os mistérios das letras e suas combinações não era tão simples como falar ou mesmo gesticular. Nesse contexto, surge na Europa, a partir do século XII, à figura da escola, que tinha entre outras, a finalidade de divulgar o idioma pátrio e a escrita e, esta por sua vez, assume a vanguarda, ficando a imagem relegada à condição de coadjuvante na compreensão do mundo. 
A escrita revolucionou a vida em sociedade ao passo que imprimiu nesta uma velocidade impressionante na absorção/divulgação de conhecimento, fornecendo novas bases para refletir as transformações no espaço. Todavia, a partir do século XIX, as inovações técnicas, o desenvolvimento do capitalismo e a expansão do comércio para além das fronteiras do Velho Mundo promoveram significativas alterações na sociedade. Num mundo cada vez mais interligado no qual há uma enorme mobilidade populacional, a imagem desponta como um instrumento de comunicação entre os povos.

No curso da História, os textos explicavam as imagens, desmitificavam-na. Doravante, as imagens ilustram os textos, remitificando-as. No curso da História, as imagens eram subservientes, podia-se dispensá-las. Actualmente, os textos são subservientes e podem ser dispensados. No decorrer da História, o iletrado era um aleijado da cultura dominada por textos. Actualmente, o iletrado participa na cultura dominada por imagens (FLUSSER, 1998, p.76).

É perfeitamente possível compreender o poder da imagem na sociedade atual. Elas estão em todos os lugares e são utilizadas para diversos fins. A globalização permitiu a formação de uma sociedade multicultural e de múltiplas linguagens por meio de uma massificação dos meios de comunicação, tornou mais acessível o conhecimento, incentivou a interpretação de mundo pela alfabetização do olhar. Essa velha e agora considerada "nova forma" de ver e ler o mundo e suas transformações passou a permitir que pessoas menos privilegiadas culturalmente pudessem opinar e interferir na construção do espaço.

A supremacia da imagem sobre escrita é ratificada por vários ramos da pesquisa científica, inclusive pela semiótica, que por meio de estudos dos signos e sinais usados em comunicação, indicou formas de expressões variadas e que estas poderiam perfeitamente ser transformadas em linguagens racionais. Cada signo passou a ser interpretado com mais rigor e assim, adquiriram maior importância na sociedade globalizada.

A linguagem verbal e/ou escrita deixou de ser a única forma de representação e comunicação humana. "Não é à toa que a revolução tecnológica que marca essa época se concentrou não na escrita - sempre mais restrita às elites e à organização política de limites nacionais -, mas no registro, reprodução e difusão de sons e imagens" (COSTA, 2005, p.19). Ou seja, a imagem retoma de vez seu lugar perante a sociedade moderna.

Os avanços tecnológicos iniciados a partir da Revolução Industrial, em fins do século XVIII, permitiram inúmeros avanços, não só do ponto de vista econômica, mas também social. Recentemente, a inserção da informática nos mecanismos de comunicação pode ser considerada como a grande responsável pelo uso de imagens em macroescala, quando os recursos visuais e audiovisuais foram inseridos mais intensamente no convívio em sociedade. A interpretação das imagens torna-se cada vez mais necessária para o entendimento dos fatos sociais e naturais. Para Manguel (2009, p. 21), "As imagens assim como as histórias nos informam. Aristóteles, apud Manguel, sugeriu que todo processo de pensamento requeria imagens". Assim sendo, sempre que necessário o indivíduo recorre às imagens armazenadas em sua mente e que foram construídas através de estímulos para ajudá-lo a compreender determinados fatos que o rodeia.

Além de reconhecer amigos e inimigos, de diferenciar presa e predadores, de situar os seres num espaço de onde podem entrar e sair, as imagens mentais que obtemos, de nossa relação com o mundo podem ser armazenadas, constituindo nossa memória, podem ser analisadas pela nossa reflexão e podem se transformar numa bagagem de conhecimento, experiência e afetividade. Desenho, pinturas e esculturas permitem que compartilhemos com os outros as emoções e sentimentos despertados na nossa relação com o mundo (COSTA, 2005, p.27).

Geografia Ensino \& Pesquisa, v. 17 n. 2 p. $88-106$, maio./ago. 2013

Girão, O.; Lima, S. R.

Nessa perspectiva, as imagens podem auxiliar no processo de ampliação da visão de 
mundo. A cultura visual é determinante para empreendermos uma mudança significativa na relação dos homens com os homens e com a natureza. Dominar a leitura de imagem permite que o homem possa redescobrir o espaço geográfico e suas transformações ao longo da evolução da humanidade. É por meio da análise, observação e da comparação que os indivíduos podem enfim posicionar-se acerca dos fatos. Por meio da leitura crítica de imagens, é possível entender como nossas experiências e nossa identidade são socialmente construídas.

Durante o Século XX, e início do Século XXI, pode-se perceber uma verdadeira revolução no que se refere aos registros iconográficos. As tecnologias de registros de imagens foram aprimoradas e estas passaram a invadir as casas e nossas vidas. Onde quer que estejamos elas se fazem presente. Saber interpretá-las, numa sociedade que muda muito rapidamente, é a base para construir um conhecimento elaborado e desenvolver uma postura crítica e, desse modo interferir positivamente na organização e (re) organização do espaço.

Estas informações podem ser melhor compreendidas se tomarmos como base, por exemplo, os satélites equipados com sensores moderníssimos que emitem imagens capazes de manter a sociedade informada a todo o momento. Uma diversidade de elementos e informações pode ser trabalhada a partir dessas imagens, porém, é preciso conhecimento prévio para poder interpretá-las e assim, transformar a informação em conhecimento. "Essa apreensão requer, além de aguçados mecanismos de percepção visual, condições culturais adequadas, dedução e comparação com outras imagens para que o intérprete possa se constituir num receptor competente" (BIANCO-FELDMAN, 1998, p. 40).

Nessa perspectiva, a escola deve ser a ponte que liga os saberes. Debruçar-se sobre as imagens como se estivesse decodificando textos, questionar, analisar, comparar, desvendar os mistérios e as informações que estão presentes em cada registro deve ser prática permanente no cotidiano escolar.

O desenvolvimento tecnológico e a globalização em curso permitem que o aluno tenha acesso a essas imagens praticamente em tempo real e a escola precisa estar preparada para lidar com esses novos saberes e o professor torna-se o "fio condutor" para que ocorra uma aprendizagem satisfatória.

Para tanto, deve-se incentivar o aluno a questionar, construir, desconstruir e reconstruir seu conhecimento. Aprender requer motivação e essa poderá vir por intermédio dos meios de comunicação que nos bombardeiam com imagens e informações que podem ser transformadas em instrumentos de apoio no ensino.

Se a leitura de mundo implica em um processo permanente de decodificação de mensagens, de articulação/contextualização das informações, cabe à escola ensinar o aluno a lê-lo também por meio de outras linguagens e saber lidar com os novos instrumentos para essa leitura (PONTUSCHKA, PAGANELLI e CACETE 2007, p. 262).

A escola deve ser um espaço privilegiado, onde os alunos desenvolvem habilidades para interpretar e decodificar textos e imagens tão características da atual revolução tecnológica e da chamada globalização. Afinal, a primeira de certa forma "popularizou" equipamentos e a segunda aproximou as culturas, ao passo que, permitiu um acesso maior às informações. Mesmo apresentando vários pontos positivos, a revolução técnico-científica-informacional e a globalização não atingem todos os espaços de forma igualitária, podendo agravar em escala

Geografia Ensino \& Pesquisa, v. 17, n. 2 p. $88-106$, maio./ago. 2013

O ensino de geografia versus leitura de imagens: resgate e valorização da disciplina pela "alfabetização do olhar" global as diferenças sociais. Solucionar, ou ao menos minimizar tais problemas é missão da escola contemporânea.

\section{O uso da imagem como facilitador da aprendizagem}

Antes de começar a falar sobre o poder da imagem como instrumento facilitador da 
aprendizagem, é de extrema importância trabalhar sua definição e sua função. De acordo com Flusser, (1998, p. 92) "as imagens são superfícies sobre as quais circula o olhar". Ou seja, tudo que nos rodeia constitui imagens que, com o passar do tempo, acumulam-se em nossa memória e nos ajudam a formular conceitos para a compreensão do espaço. Estas podem apresentar-se por meio de desenhos rupestres, fotografias analógicas, digitais e aéreas, gráficos, mapas, tabelas, charges, entre outros, e nos chegam principalmente pelos meios de comunicação em massa. Sua função principal era explicar os textos que se tornara inacessível. Seria, portanto, uma forma de orientar o homem no mundo. No entanto, o homem acabara se tornando escravo de sua própria criação.

As imagens invadiram e transformaram literalmente a sociedade. Tanto é verdade que a educação e a ciência se renderam ao poder das imagens. Hoje é impossível pensar na prática da Medicina sem o apoio incondicional das imagens para emitir diagnósticos com mais rapidez e maior precisão, e ainda realizar cirurgias de alto risco utilizando a imagem em tempo real. Todavia, a escola, parece ainda caminhar a passos lentos no que se refere à utilização dos registros iconográficos.

Ensinar e aprender em uma sociedade que muda velozmente é o grande desafio da escola no Século XXI. Graças ao grande desenvolvimento tecnológico, alcançado especialmente a partir do Século XX, e aprofundado no início deste século, as informações chegam de todas as partes do mundo por meio da TV, rádio, cinema, jornais, computador, vídeo etc. É uma verdadeira enxurrada de textos e imagens que podem e devem ser trabalhadas para a construção do saber e permitir a compreensão do espaço seja ele em âmbito local, regional, nacional ou global.

Nessa perspectiva, cabe à escola fornecer mecanismos para que o aluno se torne capaz de selecionar essas imagens e elaborar seus conceitos, favorecendo o seu desenvolvimento cognitivo. A imagem abre as portas para um mundo de possibilidades, quebrando o paradigma racional da escrita que distancia o leitor do texto. A imagem aproxima o observador, pois este pode construir e reconstruir seus conceitos, ao passo que aprofunda a sua observação, analisa e reanalisa, sendo, talvez, a forma mais eficaz para se entender o mundo e suas mudanças.

A percepção visual tem tido especial importância nas mais diferentes culturas, e ela divide com a audição o posto de principal instrumento cognitivo do ser humano (...). Sem desmerecer os demais sentidos humanos, biólogos, psicólogos e neurologistas são unânimes em reconhecer a importância da visão e da linguagem visual para grande parte das situações que devemos enfrentar ao longo da vida. A rapidez com a qual processamos informações visuais e a facilidade com que as arquivamos são argumentos fortes em favor do uso das imagens na comunicação humana (COSTA, 2005, p. 31).

Tal argumento pode ser perfeitamente aplicado ao cotidiano escolar. Ora, se somos capazes de guardar na memória essas informações, a escola precisa urgentemente rever sua prática pedagógica e buscar auxílio nas novas tecnologias. As imagens estão cada vez mais presentes na sociedade e podem contribuir para que o aluno torne-se sujeito ativo do processo de ensino-aprendizagem. Trabalhar o aluno para desenvolver uma postura crítica diante da massa de informações e mensagens que os "bombardeiam", e assim exercer sua cidadania de fato é o papel da escola, e para que isso ocorra é necessário estar disposto a encarar novos desafios. A realidade agora é virtual. Samain (1998) escreve: "Finalmente, participamos de uma revolução da visão". Pois bem, se essa revolução já chegou aos lares e conquistou seu espaço, esta deve também permear a prática pedagógica. A escola deve mergulhar no mundo das imagens e ultrapassar as barreiras que separam a cultura letrada e elitista baseada na escrita, da cultura das imagens mais acessível e menos elitizada.

Hoje, na chamada pós-modernidade, a escola deve proporcionar os caminhos necessários para que os sujeitos/alunos possam compreender o

Geografia Ensino \& Pesquisa, v. 17, n. 2 p. $88-106$, maio./ago. 2013

Girão, O.; Lima, S. R.

ISSN 2236-4994 I $\quad 93$ 
cotidiano, desenvolvendo e aplicando competências. A instituição escolar precisa acreditar que um de seus propósitos é o de motivar para a vida do aluno, muitas vezes repleta de desmotivação. Ela deve possibilitar situações para que os seus participantes desenvolvam sua auto-estima como sujeitos (REGO, 2007, p. 44).

O papel da educação, nesse sentido, é o de formar cidadão, apto a tomar decisões e fazer escolhas acerca de todos os aspectos da vida em sociedade que o afetam. Isso exige acesso à informação e a capacidade de processá-la de forma sensata sem se deixar levar pelo poder econômico ou político.

Para Rego (2007, p. 45), “Despertar e manter a curiosidade dos alunos deve ser sempre a primeira tarefa da escola e um desafio constante para os professores cujo trabalho é prazeroso, mas os resultados nem sempre são imediatos". Assim sendo, a tarefa de educar exige esforço mútuo e dedicação de todos os agentes envolvidos nesse processo.

A leitura do mundo precede a leitura da palavra" (FREIRE, 1989, p. 9).
Tanto é verdade que, nas séries iniciais, antes mesmo da criança aprender
a decodificar os textos ela é exercitada a analisar as imagens e a partir daí é
estimulada a expressar seus pensamentos e verbalizar seus textos. "Desde
muito pequenos, aprendemos a ler imagens ao mesmo tempo em que
aprendemos a falar. Muitas vezes, as próprias imagens servem de suporte
para o aprendizado da linguagem (JOLY, 2004, p. 43).

No entanto, com o passar do tempo, essa habilidade é praticamente ignorada pela escola. Alfabetizar-se não consiste só em conscientizar os códigos da língua falada e escrita, mas os códigos de todas as linguagens do homem atual e de sua interação. O desenvolvimento do conhecimento é um dos aspectos fundamentais da escola e deve ser acompanhado do desenvolvimento de habilidades e de atitudes. Habilidades que levem o indivíduo a caminhar sozinho, a expressar-se melhor, colaborando para chegar a uma sociedade mais justa. Porém, ainda é necessário percorrer um longo caminho que conduza o aluno a construir seu próprio conhecimento. O problema é que nem todas as escolas estão preparadas para lidar com os novos saberes que a atual sociedade exige. A esse respeito:

O modelo educacional que temos hoje foi desenhado no século XVIII e está centrado na oralidade, na escrita e na repetição e memorização dos conteúdos. A superação desse modelo é a condição para a inclusão da escola no século XXI e passa, obrigatoriamente, pela adoção de novos pressupostos no que diz respeito à produção e difusão de conhecimentos válidos (...). Mesmo admitindo que a imagem e a linguagem audiovisual ajudaram a configurar o que somos e como nos vemos, contraditoriamente, ainda não lhes concedemos na escola legitimidade semelhante à que conferimos, historicamente, aos textos escritos, sobretudo no que diz respeito à produção e difusão de conhecimentos e informações considerados válidos (DUARTE, 2006, p. 228 e 232).

A linguagem visual e audiovisual desenvolve múltiplas atitudes. Um fato mostrado com imagem e palavras tem muito mais força do que se somente mostrado com a palavra. Essa relação de complementaridade contribui para que funcionem de forma eficaz. "Assim, quer queiramos, quer não, as palavras e as imagens revezam-se, interagem, completam-

Geografia Ensino \& Pesquisa, v. 17, n.2 p. $88-106$, maio./ago. 2013

O ensino de geografia versus leitura de imagens: resgate e valorização da disciplina pela "alfabetização do olhar" se e esclarecem-se com uma energia revitalizante" (JOLY, 2004, p.133). Muitas situações importantes do cotidiano perdem força, por não terem sido valorizadas pela imagem-palavra. Ver é extremamente importante para ler o mundo. No entanto, "Existem aqueles casos em que o divórcio entre os dois é completo. A leitura atenta pode isolá-los, ignorando um e levando em conta apenas o outro" (BIANCO-FELDMAN, 1998, p. 38). Uma imagem diz muito mais do que captamos, pois, aguça nossa curiosidade e nos permite investigá-la com mais afinco. 


\begin{abstract}
A imagem pode e deve ser utilizada como uma narrativa visual que informa o relato etnográfico com a mesma autoridade do texto escrito. Mais do que representar fatos visíveis, tais imagens acrescentam outros meios de representação à descrição etnográfica (...). Mais ainda, a análise de registros fotográficos tem permitido a reconstituição da história cultural de alguns grupos sociais, bem como um melhor entendimento dos processos de mudança social, do impacto do colonialismo e da dinâmica das relações interétnicas. Arquivos de imagens e imagens contemporâneas em pesquisa de campo podem ser utilizados como fontes, que conectam os dados coletados a tradição oral e à memória de grupos estudados. (BIANCO-FELDMAN, 1998, p.199 e 200).
\end{abstract}

Se as imagens já são amplamente utilizadas pelas ciências sociais no campo científico, a escola que é o espaço privilegiado de produção de conhecimento necessita agarrar-se a essa "nova" forma de produzir o saber.

Várias disciplinas poderão envolver-se nessa verdadeira empreitada a fim de resgatar o interesse do aluno. A imagem não precisa necessariamente estar ligada as Artes ou a Matemática. Ela está presente na História, na Biologia, na Língua Portuguesa entre outras, e é extremamente importante trabalhá-la.

Todavia, é na Geografia que ela realmente encontra grande apoio, pois, como entender as transformações no espaço sem a análise dos registros iconográficos? Como estudar os climas, sem a compreensão da dinâmica das massas de ar e de sistemas atmosféricos secundários, ou ainda, sem um estudo aprofundado sobre a gênese e processos atuantes na modelagem do relevo? Como falar do crescimento urbano sem analisar gráfico e tabelas? Como localizar-se no espaço sem o apoio de mapas ou outros instrumentos de localização? Enfim, são inúmeros os motivos que elevam a importância de analisar os registros iconográficos em Geografia para que se possa compreender melhor o espaço geográfico e suas transformações em diferentes sociedades e em diferentes épocas.

\title{
A Geografia e o uso de imagens: resgate e valorização por meio da "alfabetização do olhar"
}

Depois de ter se tornado uma ciência autônoma no Século XIX, a Geografia chega ao final do Século XX e início do Século XXI com interesses e objetivos renovados. Um ensino renovado e crítico não consistem de apenas de novos conteúdos, mas também numa mudança de técnicas ou estratégias pedagógicas, que proporcionem ao aluno a leitura, a pesquisa, o diálogo, a interpretação e a ligação entre conhecimento científico e sua vida cotidiana, e que contribuam para a formação de sujeitos críticos, capazes de atuar conscientemente no meio em que vivem, tendo um olhar questionador sobre a realidade, visando a sua autonomia intelectual.

De acordo com a concepção sócio-interacionista, os professores ao ensinarem geografia devem aliar à teoria à prática, valorizar experiências e conhecimentos prévios e propor desafios passíveis de discussões que facilitem e promovam a construção de conceitos e práticas geográficas significativas. O papel da Geografia é alfabetizar espacialmente o aluno em suas diversas escalas e configurações buscando decodificar as imagens presentes no cotidiano, impressas e expressas na paisagem e em suas representações.

Segundo as orientações curriculares para o ensino médio (BRASIL, 2006, p. 43), a Geografia, como componente do currículo do ensino fundamental e médio “(...) deve preparar o aluno para: localizar, compreender, e atuar no mundo complexo, problematizar a realidade, formular proposições, reconhecer as dinâmicas existentes no espaço geográfico, pensar e atuar criticamente em sua realidade tendo em vista a sua transformação".

Nesse sentido, a escola passa a ser o espaço de formação e informação, em que a aprendizagem de conteúdos deve necessariamente favorecer a inserção do aluno no dia a dia das questões sociais marcantes e em um universo cultural muito maior. A formação escolar

Geografia Ensino \& Pesquisa, v. 17, n. 2 p. $88-106$, maio./ago. 2013

Girão, O.; Lima, S. R.

ISSN 2236-4994 I 95 
deve propiciar o desenvolvimento de capacidades, de modo a favorecer a compreensão e a intervenção nos fenômenos sociais e culturais, e assim contribuir para a transformação de sua realidade social.

A sociedade é cada vez mais uma sociedade da informação, fruto da
revolução tecnológica responsável pela rapidez cada vez maior dos meios
de comunicação. Entretanto, pode-se dizer que tal situação não tem
garantido a inserção crítica dos indivíduos na sociedade, uma vez que, via
de regra, as informações são descontextualizadas e fragmentadas (...). O
desenvolvimento das tecnologias de informação possibilitou o registro de
informações geográficas em forma digital, aumentado em muito a quantidade
de informações disponíveis para o uso no processo de análise do espaço
geográfico (PONTUSCHKA, PAGANELLI e CACETE 2007 p.261 e 264).

No referente ao ensino da Geografia, apesar de serem muitos os meios disponíveis para se trabalhar os conteúdos geográficos, a maioria das escolas insiste em trabalhá-los de forma descontextualizadas. A prática da utilização das imagens para a compreensão do mundo é de certa forma desprezada por vários professores, isso pode ser comprovado quando analisamos, por exemplo, questões propostas pelo Exame Nacional do Ensino Médio (ENEM), que exigem a leitura de mapas e imagens, e que evidenciam certa dificuldade para os alunos.

Contudo, o estigma de ciência de memorização, que ainda acompanha o ensino de Geografia, remete o aluno a, de certa forma, menosprezar a Geografia como uma ciência fácil de ser compreendida face o seu caráter "decorativo".

No entanto, a Geografia hoje como ciência social busca aplicações de seus estudos junto à sociedade, como objeto de pesquisa, objetivada pela análise da organização e reorganização do espaço geográfico, sendo esta questionadora, em busca da compreensão do espaço por meio de diferentes linguagens.

Desenvolver nos alunos a habilidade de compreender o espaço por meio da observação é talvez uma forma de resgatar o interesse dos alunos pela disciplina. Para tanto, o professor deve estar preparado para trabalhar os conteúdos da disciplina de forma dinâmica, prazerosa que seja capaz de levar os alunos a adquirirem competências, e assim tornarem-se aptos a construir seu conhecimento.

Várias ferramentas de apoio estão à disposição do professor, principalmente nos meios de comunicação. São textos e imagens que deve ser aproveitadas para incrementar o trabalho em sala de aula. O problema está justamente na forma de utilização dessas imagens. Ainda segundo Pontuschka, Paganelli e Cacete (2007, p. 278), "A imagem, no ensino de Geografia, geralmente é empregada como mera ilustração". Sendo assim, o professor deixa de utilizar uma peça importantíssima na elevação da autoestima de seus alunos e no resgate e valorização da disciplina.

O trabalho com imagens em geografia é tão importante quanto o trabalho com mapas, e ambos, geralmente são pouco usados. Desde fotografias que mostram paisagens, que não sofreram ação de seres humanos, até as que representam obras feitas por eles - como prédios, plantações, fábricas, favelas, meios de transportes, máquinas-, todas podem ser interpretadas pela geografia (REGO, 2007, p. 18).

Geografia Ensino \& Pesquisa, v. 17, n. 2 p. $88-106$, maio./ago. 2013

O ensino de geografia versus leitura de imagens: resgate e valorização da disciplina pela "alfabetização do olhar"
Com frequência, os alunos reclamam das aulas de Geografia. Expressões de desagrado e desestímulo em relação à matéria são comuns e constantes. Na verdade, é preciso repensar à prática pedagógica e passar a trabalhar de modo a atribuir significado ao aluno. É necessário, portanto, que a escola esteja preparada para encarar novos desafios e apoiar o professor numa prática renovada que possa ser capaz de atrair a atenção do aluno, despertando neste o gosto e o prazer em adquirir novos conhecimentos. 
Ao trabalhar com os conceitos cartográficos e geográficos, tendo como interfaces as categorias de espaço e tempo, temos de incorporar outros componentes que servirão de referências curriculares para o ensino médio, ou seja, admitir a diversidade de fontes e de linguagens, valorizando as leituras objetivas e subjetivas de mundo. Essas linguagens (cartográfica, textual, corporal e cênica, iconográfica e oral) servirão de apoio para as aulas de Geografia, ou seja, são um instrumento mais adequado para fazer a leitura do meio geográfico e de seu uso, o que supõe o exercício da interdisciplinaridade (BRASIL, 2006, p.50).

A civilização moderna dispõe de vários registros que podem auxiliar neste processo. As imagens são tantas e de todos os tipos. São fotografias, imagens de satélites, tabelas, gráficos, mapas, vídeos, entre outros, e a escola deverá preparar o aluno para lidar com tais avanços. Nesse contexto, cabe a Geografia, analisá-las, compará-las, questioná-las para assim, compreender seu objeto de estudo que é o espaço geográfico constantemente construído e reconstruído pela ação do homem.

O homem sempre utilizou as imagens. Na Pré-História, deixou suas marcas, analisou o espaço a partir de pegadas de animais, alfabetiza-se por meio de imagem, está sempre preocupado com sua imagem particular, utiliza as imagens para traçar o roteiro de uma viagem, usa um mapa para se localizar no espaço, utiliza gráfico e tabelas para comparar e demonstrar, por exemplo, o crescimento populacional, os satélites fotografam a terra em tempo real, sendo utilizados meteorologicamente, bem como estrategicamente.

Por tudo isso, faz-se necessário um olhar especial sobre as imagens que nos chegam de toda parte. Debruçar-se sobre elas e desvendá-las sem intervenções políticas, econômicas e religiosas deve ser o caminho a ser percorrido. Lançar um novo olhar, analisar criteriosamente os elementos explícitos e implícitos que uma imagem pode conter é um processo deveras prazeroso.

\section{Fotografias, figuras e charges como facilitadores da aprendizagem}

As imagens são exemplos de material visual que tornam os textos complementares no processo de ensino-aprendizagem, porém não dispensáveis. As figuras que se seguem são vetores facilitadores do processo de ensino da Geografia, proporcionando a oportunidade aos alunos de analisá-las e emitir opiniões.

Para iniciar nossa exposição, apontamos as desigualdades sociais existentes em países periféricos, consequência de uma excessiva concentração de renda, presente no campo ou nas cidades, e que prevalecem desde o período em que estes eram colônias de exploração de países centrais.

Na Figura 1, a catadora de lixo evidencia a baixa qualidade de vida da população periférica de grandes centros urbanos, a exemplo do Rio de Janeiro que, segregadas espacialmente e socialmente, buscam seu sustento a partir do recolhimento de objetos para consumo próprio, ou para venda junto a cooperativas voltadas para a reciclagem, que reflete a expansiva proliferação do subemprego presente nas grandes metrópoles.

No entanto, além da questão relativa à segregação no espaço urbano, outras abordagens podem ser feitas acerca da Figura 1, como a questão da globalização econômica excludente, que agrava a pobreza e a miséria, a ausência de políticas públicas que estimulem a geração de emprego e renda, o acesso à moradia, saúde, segurança e educação de qualidade para os menos favorecidos economicamente.

Ademais, a ausência de fiscalização e gerenciamento ambiental, que permite a moradores construir em áreas de risco, sujeitando-se, sobretudo em época de chuvas intensas e recorrentes, a deslizamentos, e a consequentes prejuízos materiais ou mesmo a perda de vidas humanas. Geografia Ensino \& Pesquisa, v. 17 ,
n. 2 p. $88-106$, maio./ago. 2013

Girão, O.; Lima, S. R.

ISSN 2236-4994

I $\quad 97$ 
Figura 1- Criança catando lixo na periferia do Complexo do Alemão/RJ.

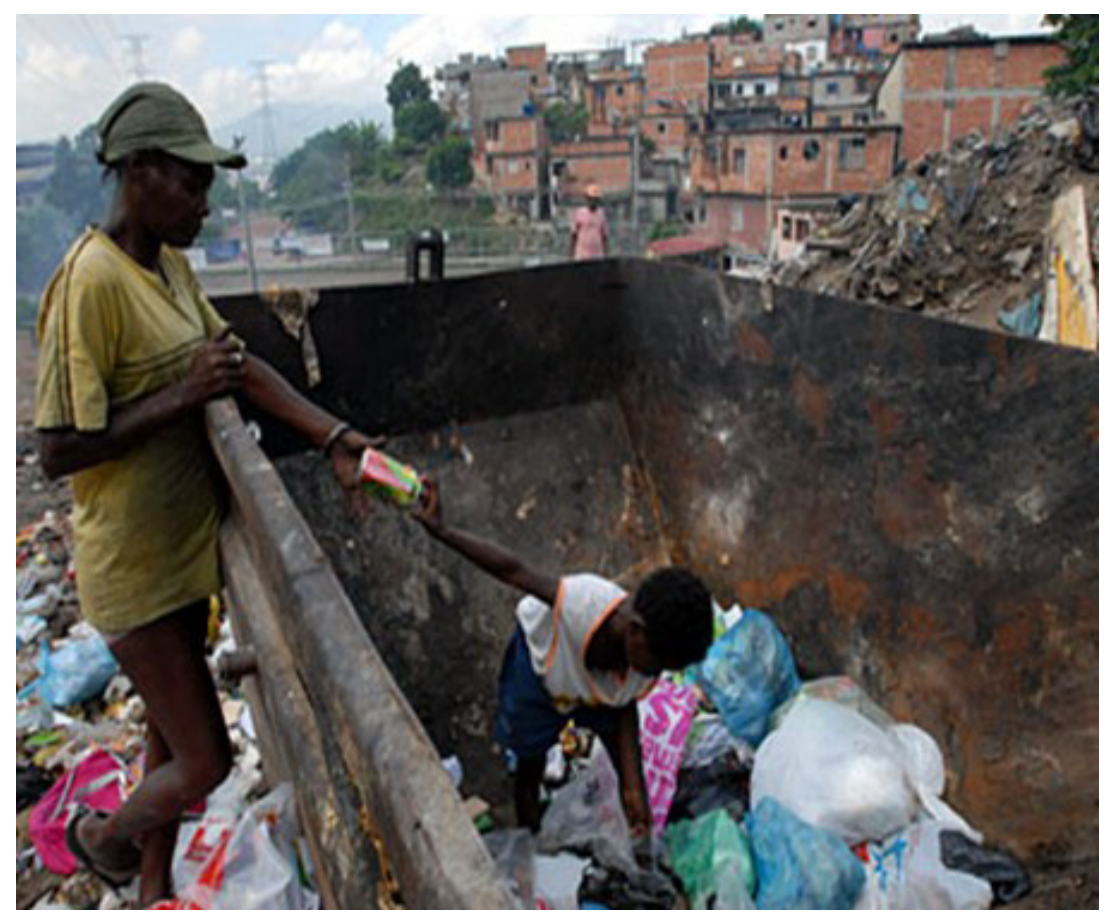

Fonte: www.vivafavela.com.br - Rodrigo Nogueira

Ainda com relação à questão do risco, o crescimento das cidades gera espaços desiguais (Figura 2). A rapidez com que ocorreu o processo de crescimento urbano no Brasil, nas últimas décadas, contribuiu para agravar as desigualdades sociais.

Na Figura 2, esta desigualdade é aparente, a partir da visualização de palafitas no bairro dos Coelhos, no centro da cidade do Recife, e o complexo hospitalar, privado, em franca verticalização, ambos disputando o espaço com os manguezais as margens do rio Capibaribe. Riqueza e pobreza convivem lado a lado sem que se misturem. É praticamente impossível pensar, por exemplo, num morador das palafitas recebendo atendimento médico nesses hospitais.

Além das desigualdades sociais, o aluno pode levantar questionamentos sobre os investimentos em infraestrutura, saúde, educação, política habitacional, globalização que exclui, aprofundando o abismo entre riqueza e pobreza e pode comparar essa realidade com seu município e com outras metrópoles brasileiras.

Outra forma de compreender o crescimento urbano pode ser feita por meio da análise de imagens do lugar, pois, este tem para o aluno um significado especial, em virtude de desenvolver com este uma relação de identidade. "Estudá-lo é fundamental, pois ao mesmo tempo em que o mundo é global, as coisas da vida, as relações sociais se concretizam nos lugares específicos" (CALLAI, 2009, p. 84).

A exemplo da utilização de fotografias e imagens relativamente recentes, a utilização de imagens antigas e recentes também contribui para a fixação de conceitos a exemplo do

Geografia Ensino \& Pesquisa, v. 17, n. 2 p. $88-106$, maio./ago. 2013

O ensino de geografia versus leitura de imagens: resgate e valorização da disciplina pela "alfabetização do olhar"

98 I ISSN 2236-4994 crescimento urbano e urbanização e suas conseqüências para o homem e para o meio natural.

A Figura 3, publicada pelo Diário de Pernambuco em (O fim do bucolismo de Casa Forte, 2010) mostra a evolução e o crescimento rápido do bairro de Casa Forte, área central da cidade do Recife/PE. A paisagem bucólica da década de 1940 cedeu lugar aos espigões, construídos em função do aumento populacional, bem como da crescente especulação imobiliária. Há que se destacar também o crescimento da violência, o aumento do custo de vida, o aumento do comércio, o aumento da poluição, entre outros. 
Figura 2- Contraste social no bairro dos Coelhos, centro da cidade do Recife-PE. As margens do rio Capibaribe a erradicação do mangue dá lugar a mocambos.

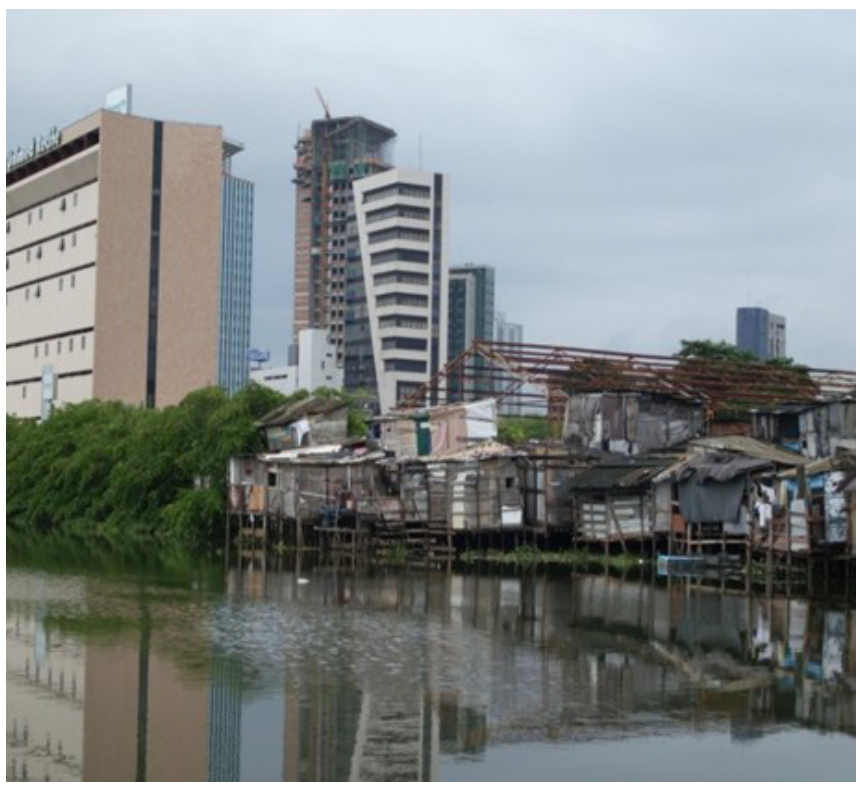

Fonte: Surama Lima, 18/04/2009.

Além dos aspectos relativos à Geografia dita Humana, a Geografia Física também pode ser bem compreendida com o apoio de imagens. A Figura 5, abaixo, coletadas de Coelho e Terra (2002), sugere uma abordagem sobre a climatologia e sua influência para a sociedade a partir do estudo da dinâmica sazonal das massas de ar atuantes sobre o território brasileiro.

Figura 3- Praça da Vitória Régia, no bairro de Casa Forte em Recife-PE na década de 1940 (à esquerda). A mesma localidade em 2009 (à direita), com casarios e edifícios que substituíram a vegetação de outrora.

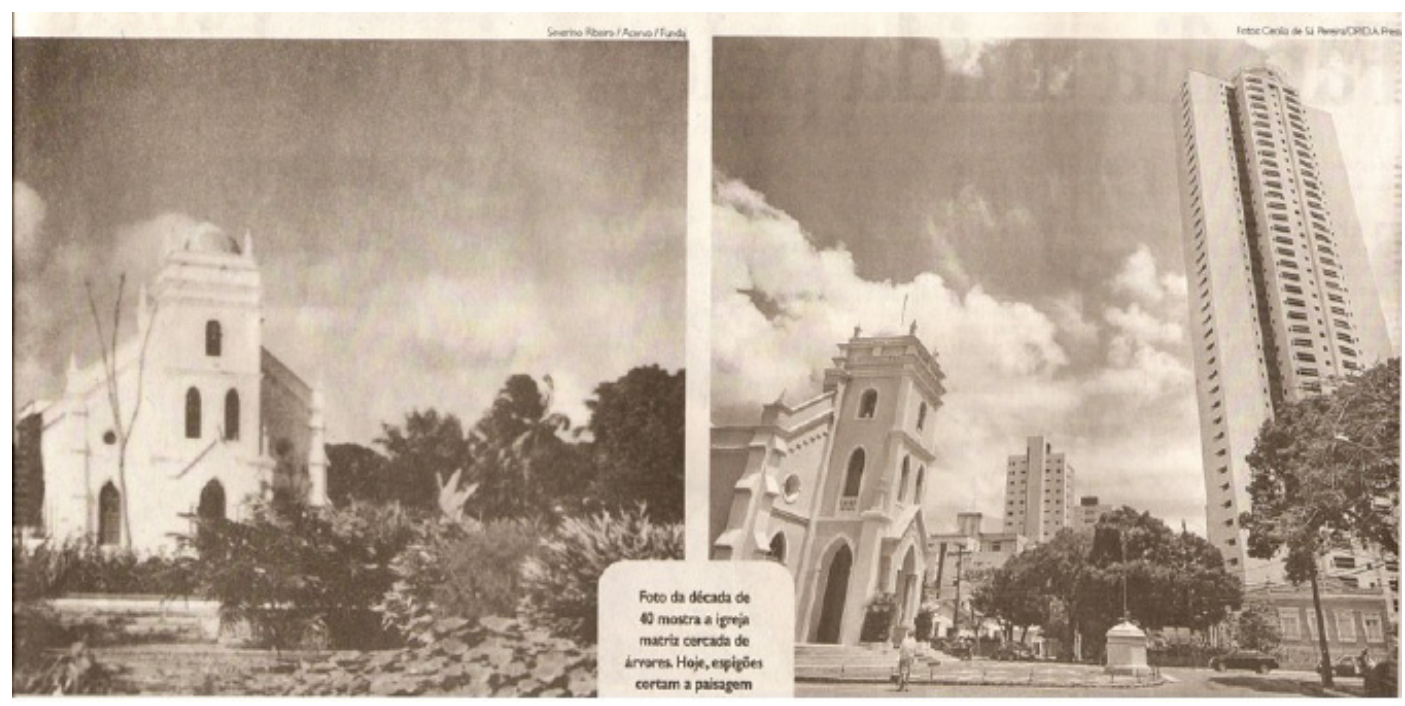

Fonte: O fim do bucolismo de Casa Forte (2010).

A partir da análise da Figura 4, podem-se trabalhar os conceitos de massas de ar e sua atuação ao longo do ano interferindo no regime das chuvas no Brasil. Ainda com o apoio da figura em questão, é possível fazer comparações com as imagens de satélites para que o aluno torne-se apto a compreender a ocorrência das chuvas em seu município e a relações do clima local com as atividades econômicas e com os costumes da população municipal.

Geografia Ensino \& Pesquisa, v. 17, n.2 p. $88-106$, maio./ago. 2013

Girão, O.; Lima, S. R. 
Através de imagens de satélites, o aluno pode compreender, e inclusive acompanhar, via internet, a dinâmica de sistemas atmosféricos atuantes em sua região, e assim entender como funciona o regime pluviométrico da mesma (Figura 5), haja vista que, entender a variação climática é de extrema importância para grupos sociais e para o desenvolvimento de atividades econômicas.

Figura 4- Atuação de massas de ar sobre o território brasileiro durante o verão e o inverno austral.

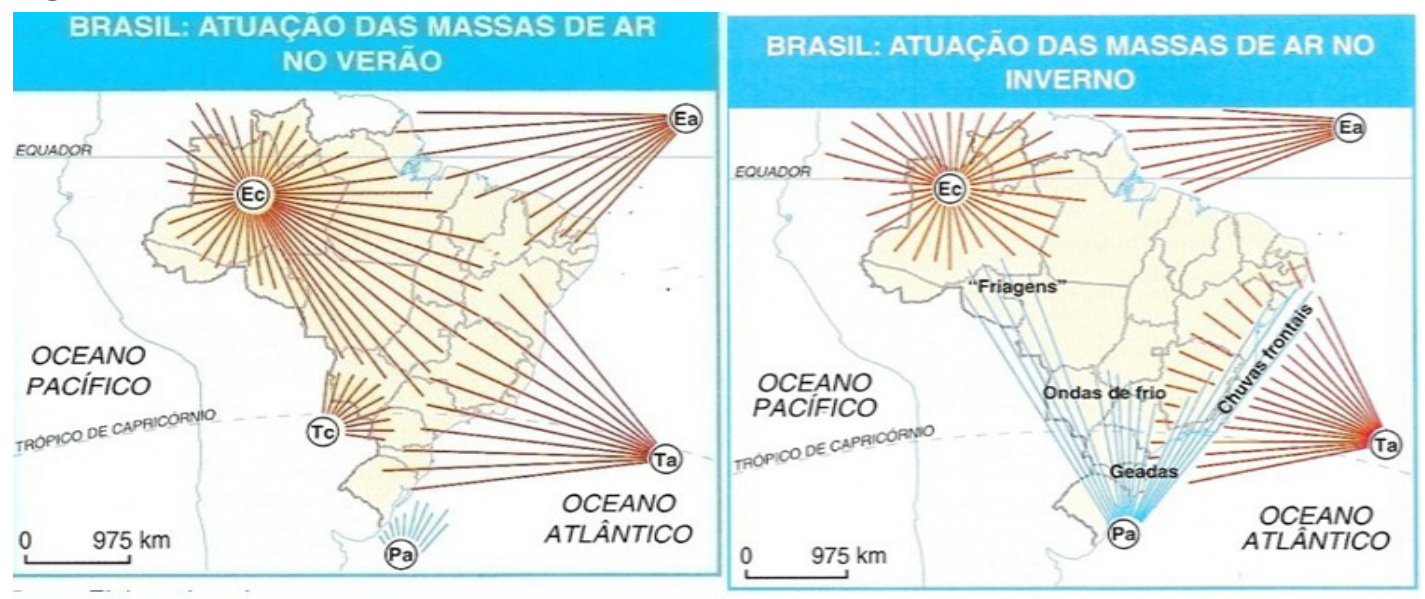

Fonte: Coelho e Terra (2002, p. 83).

Figura 5- Atuação de sistemas atmosféricos secundários durante o inverno, no caso, o avanço da Frente Polar Atlântica (FPA) sobre o litoral nordestino (à esquerda) e a ação de fluxos da Zona de Convergência Intertropical (ZCIT) sobre a porção norte do Nordeste durante o verão (à direita).

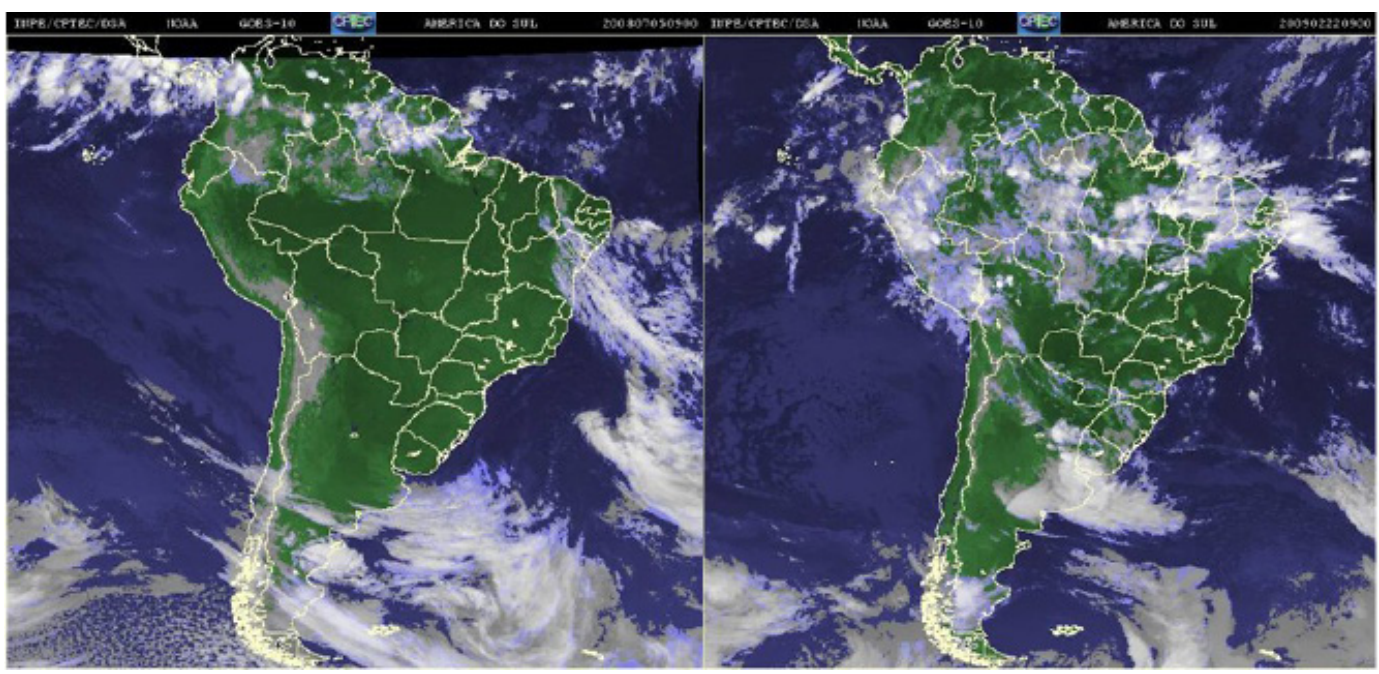

Fonte: www.cptec-inpe.br, imagens de satélite de 05/07/2008 - GOES 10 (à esquerda) e de 22/02/2009 - GOES 10 (à direita).

As imagens produzidas pelos satélites podem ser utilizadas para diversos outros

Geografia Ensino \& Pesquisa, v. 17, n.2 p. 88-106, maio./ago. 2013

O ensino de geografia versus leitura de imagens: resgate e valorização da disciplina pela "alfabetização do olhar"

$100 \quad$ I ISSN 2236-4994 fins. Por meio delas, ainda é possível estudar sobre agrometeorologia, análise da cobertura vegetal, monitoramento de queimadas, mapeamento de secas e inundações, estudos de solos e desertificação, modelagem do equilíbrio hídrico, administrações das áreas litorâneas, monitoramento da poluição oceânica, movimentação das correntes marinhas, entre outros. É um recurso que não pode ser desprezado pelo professor de Geografia, pois contém uma gama de informações úteis e indispensáveis para o reconhcimento da dinâmica climática e suas repercussões sobre o ambiente físico e social. 
Com relação a utilização de fotografias obtidas através de excursões pedagógicas, a imagem produzida "in loco" por meio da observação e experiências vividas, o professor de Geografia poderá contribuir para a aprendizagem de seus alunos ao levar para a sala de aula imagens do que o aluno não conhece em sua vivência, sendo possível estabelecer comparações. Com as fotografias a seguir, suntos como relevo, cobertura vegetal, tipos de rocha e processo de intemperismo (Figura 6), poderão ser trabalhados com mais facilidade.

Figura 6- Vista do declive da Serra das Russas (escarpa do Planalto da Borborema), município de Gravatá, Agreste de Pernambuco (à esquerda). Imagem de uma rocha granítica sofrendo processo de intemperismo (esfoliação concêntrica) no interior do Parque da Pedra Furada, município de Venturosa, Agreste de Pernambuco (à direita).

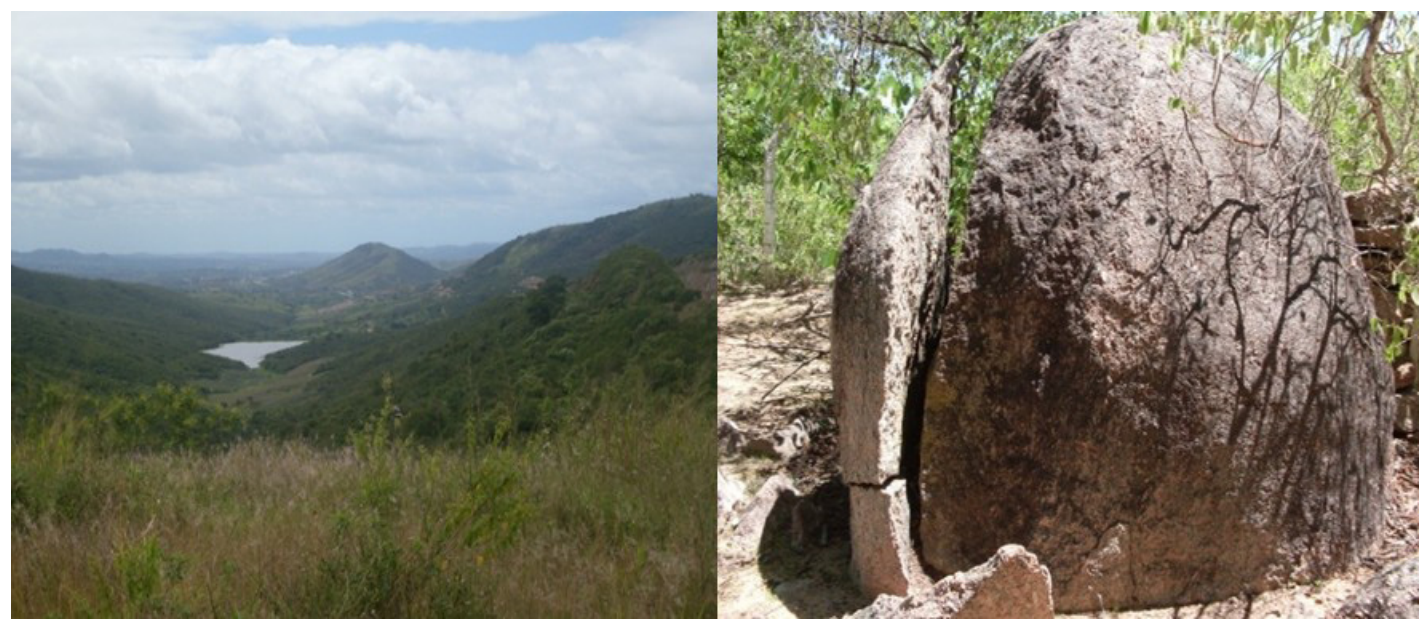

Outra forma de imagem que pode ser largamente utilizada em sala de aula como instrumento de apoio para aulas dinâmicas são as charges, instrumentos que favorecem a interação e o debate em uma linguagem acessível e de caráter cômico.

Ao analisar a Figura 7, é possível apontar o crescimento do trabalho informal nas grandes cidades, motivado principalmente pela falta de qualificação profissional, fato que acarreta inúmeras conseqüências para o país, haja vista que estes trabalhadores, em sua maioria, não contribuem para o sistema previdenciário, e consequentemente, ficam sem assistência quando se encontram, por algum motivo, impedidos de realizar suas atividades.

Figura 7- Elaborado pela Puccamp - SP

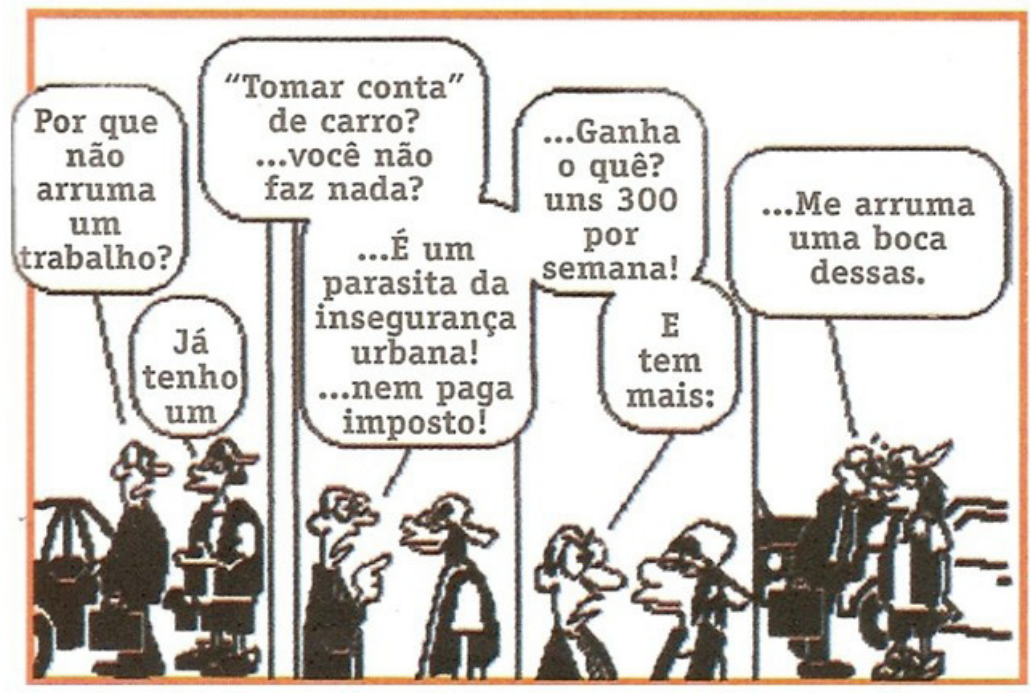

In: MOREIRA e SENE, 2005, p. 77. 
Além disso, é importantíssimo destacar que o trabalho informal é uma consequência de uma política econômica que beneficia poucos, em detrimento de uma maioria, refletindo a ausência de investimentos públicos em setores básicos como a educação, responsável pela qualificação de mão de obra.

A Figura 8 faz alusão aos protestos e invasões realizados pelo Movimento dos Sem Terra (MST) em várias capitais brasileiras durante o mês de abril de 2010 (abril vermelho). A análise da charge permite que professores e alunos comentem sobre a origem dos movimentos sociais no campo e sua luta pela reforma agrária, as causas e as consequências da concentração de terra e renda no país.

Outro ponto a ser destacado é a violência no campo provocada durante o processo de ocupações. Vale destacar ainda, o direito de ir e vir do cidadão previsto na constituição e que nesta situação é totalmente desrespeitado tendo em vista que, os manifestantes ocupam as principais vias das cidades provocando um caos generalizado no fluxo de pessoas e mercadorias.

Figura 8- Fonte: Diário de Pernambuco, 20 de abril de 2010. Caderno B. p.4.

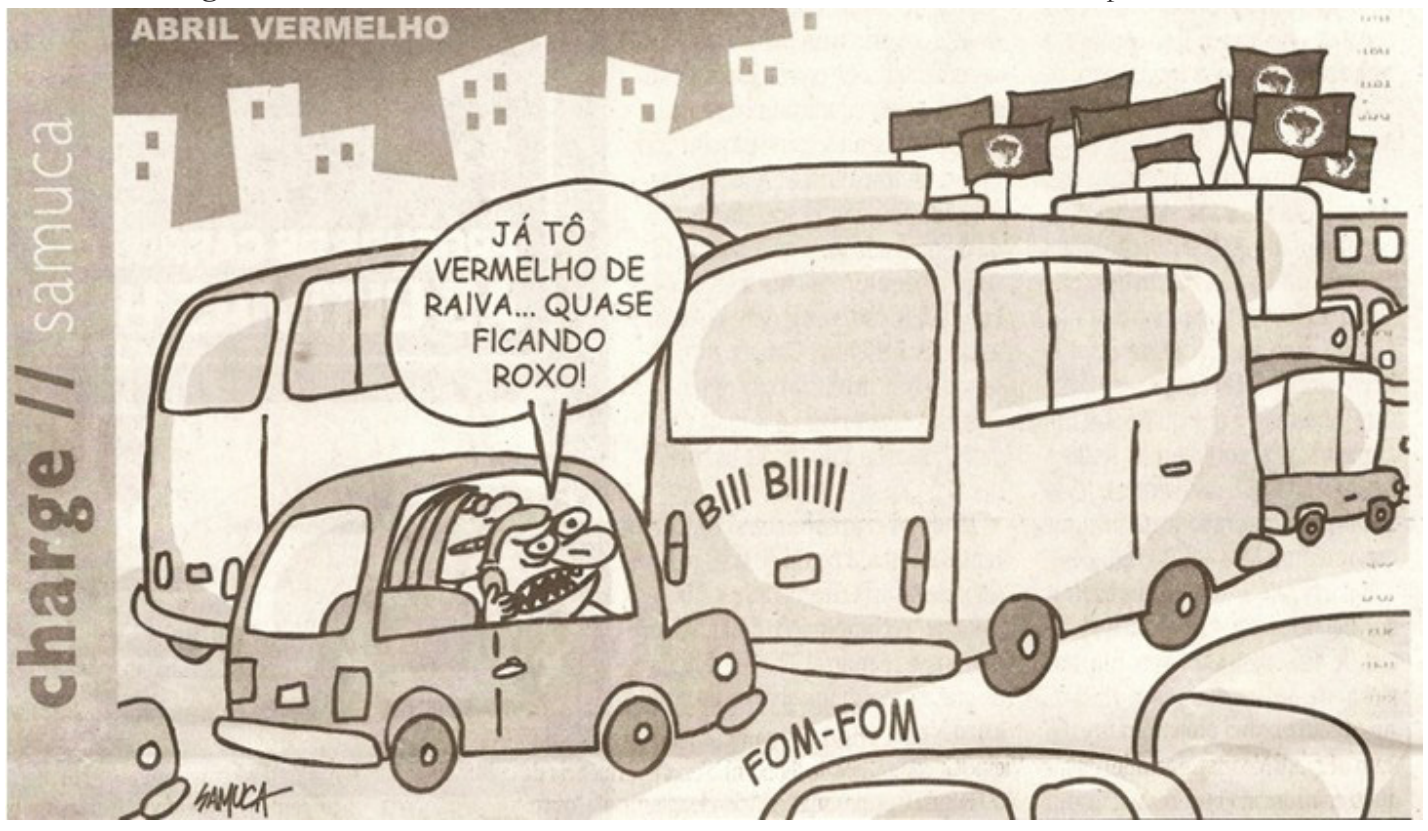

\section{A imagem na sala de aula: análise quantitativa de resultados}

Objetivando avaliar a pertinência do uso de imagens nas aulas de Geografia, foi realizada uma pesquisa na Escola João Cavalcanti Petribú, na cidade de Carpina/PE, junto a alunos do $3^{\circ}$ ano A do Ensino Médio e do $4^{\circ}$ Normal Médio (Magistério), totalizando 46 discentes. O instrumento utilizado para coleta de dados foi um questionário com perguntas fechadas, visando levantar informações acerca da percepção dos alunos acerca do uso de imagens em sala de aula e sua contribuição para o processo de ensino-aprendizagem.

A seguir, apresentamos os resultados e a interpretação dos dados referentes às perguntas

Geografia Ensino \& Pesquisa, v. 17, n. 2 p. $88-106$, maio./ago. 2013

O ensino de geografia versus leitura de imagens: resgate e valorização da disciplina pela "alfabetização do olhar"

102 I ISSN 2236-4994 constantes no questionário aplicado aos alunos.

\section{A influência do uso da imagem associada ao texto na aprendizagem}

Quando perguntado aos alunos se o uso da imagem facilita a aprendizagem, 89\% afirmaram aprender melhor com o uso da imagem associada ao texto; $9 \%$ dos entrevistados responderam que aprendem apenas com o uso da imagem sem o apoio do texto; $2 \%$ preferem 
apenas a exposição oral como elemento de aprendizagem e nenhum dos alunos apontou para apenas o texto escrito como suporte para a aprendizagem. Portanto, é possível compreender que a imagem facilita a aprendizagem, pois, a velocidade com as quais as processamos contribuem para a fixação dos conteúdos.

\section{A prática de ensino com o uso de imagem e sem o uso de imagem}

Nesse item os entrevistados tiveram a oportunidade de fazer uma análise comparativa entre as aulas que utilizam a imagem como suporte e as aulas que não utilizam o mesmo suporte. Então, $73 \%$ dos entrevistados afirmaram que tem mais dificuldade quando o professor não utiliza imagens; $25 \%$ afirmaram que se sobressai nas disciplinas onde o professor faz uso constante das imagens; $2 \%$ afirmaram que aprendem normalmente, independente do uso da imagem, todos os alunos opinaram sobre essa questão. Com este item podemos questionar: Se é mais fácil aprender com o apoio das imagens, porque insistimos em não usá-la? É necessário, portanto, que o professor atente para essa "nova" forma de produzir conhecimento.

\section{O uso da imagem na disciplina Geografia}

No que se refere ao uso da imagem na disciplina Geografia, 57\% dos entrevistados afirmaram que o uso da imagem é importante, pois, a partir dela compreendem melhor o espaço e suas transformações; 43\% afirmaram que a imagem facilita a aprendizagem à medida que a observação e a compreensão dos registros iconográficos permitem melhor compreensão dos conteúdos; com relação as opções em que o uso da imagem não interfere na aprendizagem ou é dispensável nenhum aluno opinou. Nesse item, percebe-se o poder que a imagem exerce dentro da disciplina Geografia. O as mudanças no mundo contemporâneo são rápidas intensas, e para compreendê-las, é preciso estar disposto a analisar os fatos por meio de linguagens múltiplas, afinal, a Revolução Tecnológica permitiu a formação de uma sociedade predominantemente visual, e a escola, em especial a Geografia, necessita despertar no aluno a curiosidade e a busca pelo conhecimento a partir dos meios que lhe são propostos.

\section{As imagens de satélites no ensino de Geografia}

Nessa questão os alunos foram indagados sobre a ajuda das imagens de satélites no ensino de Geografia. Dos entrevistados, $82 \%$ responderam que ajudam, pois, esse recurso permite conhecer informações sobre os climas, crescimento urbano, queimadas, entre outros; $7 \%$ responderam que quando a imagem é compreendida ajuda e $11 \%$ responderam que não prestam atenção as imagens de satélites e nenhum aluno respondeu o item que indica a inoperância do uso da imagem de satétite. Em suma, a maioria aponta para a contribuição das imagens produzidas pelos satétiles no processso de aprendizagem, todavia, é um recurso ainda pouco utilizado em função da sua complexidade e demonstra que existe um despreparo especialmente na formação do professor, refletindo diretamente na formação do aluno.

\section{O uso da imagem no livro didático}

Quanto a presença de imagens nos livros didáticos como suporte para compreensão de texto e melhor aprendizagem, 55\% dos alunos afirmaram serem esses elementos importantes aliados, pois, um texto mostrado pela palavra-imagem torna-se mais acessível aos leitores; $35 \%$ afirmaram que as imagens do livro didático, são subsídios para entender o texto escrito; $4 \%$ afirmaram que as imagens são dispensáveis, pois, o texto escrito é a forma segura e racional de se transmitir conhecimento e $2 \%$ não assinalaram as alternativas apresentadas. Portanto,

Geografia Ensino \& Pesquisa, v. 17, n. 2 p. 88-106, maio./ago. 2013

Girão, O.; Lima, S. R.

ISSN 2236-4994

I 103 
pode-se perceber que livros que contem imagens, apoiando o texto, são mais bem aceitos pelos alunos em função de poderem analisar, comparar e questionar diferentes paisagens e realidades. É no confronto de informações e imagens que a aprendizagem torna-se agradável e prazerosa.

\section{O uso de filmes e propagandas em sala de aula nas diversas áreas de ensino}

Com relação ao uso de filmes e propagandas, $57 \%$ dos alunos responderam que facilita a aprendizagem, pois o ver é extremamente importante para ler o mundo e suas transformações; para 41\% dos entrevistados, se utilizados de forma adequada são importantes aliados no processo de ensino aprendizagem; com relação as alternativas que continham o uso de filmes e propagandas como mero ilustradores não contribuindo para a formação cidadã e a não utilização desses recursos pelos professores, nenhum aluno as assinalaram; $2 \%$ não responderam a essa questão. A análise do resultado mostra claramente a importância da utilização deste recurso em sala de aula, pois contribuem para a formação de um cidadão capaz de atuar no mundo e fazer as mudanças necessárias para a construção de uma sociedade com menos desigualdade.

\section{O estudo da Geografia com o apoio de fotografias e filmes}

Nesse item $71 \%$ dos entrevistados afirmaram que são grandes aliados, pois, pemitem conhecer e comparar realidades distintas sejam elas sociais, ambientais ou culturais, contribuindo para uma assimilação de conteúdos melhorando a aprendizagem; $27 \%$ afirmaram que a utilização desses recursos, torna a aprendizagem mais prazerosa melhorando o rendimento escolar; nenhum aluno assinalou as alternativas que rejeitavam e/ou não concordavam com a utilização de filmes e fotografias por darem margens a várias interpretações; $2 \%$ dos entrevistados não respondeu a esse item. A interpretação desses dados, aponta para um ensino de Geografia renovado, crítico, capaz de despertar e recuperar a vontade e o prazer em aprender a disciplina. A prática de utilização de imagem pela Geografia torna-se um instrumento de resgate do aluno, que durante muito tempo atribuiu a essa disciplina um título de matéria desinteressante e desinteressada em função de sempre recorrer a forma de aprimorar conhecimento por meio da memorização, prática que na atualidade, é perfeitamente dispensável, pois, a Geografia visa a construção da cidadania plena e para que isso ocorra, deve buscar uma nova forma de alfabetização, que exige um outro sentido - é a "alfabetização do olhar."

\section{Considerações finais}

São inúmeras as possibilidades de utilização das imagens em sala de aula. Além dos exemplos aqui citados, existem ainda outras fontes que não podem ser esquecidas. Os filmes, as propagandas, trechos de telenovelas, documentários, matérias jornalísticas entre outros podem ser perfeitamente utilizados para tornar as aulas mais atraentes, dinâmicas, prazerosa e acessível aos alunos. Novas práticas pedagógicas para uma nova sociedade. Essa deve ser a

Geografia Ensino \& Pesquisa, v. 17, n. 2 p. 88-106, maio./ago. 2013

O ensino de geografia versus leitura de imagens: resgate e valorização da disciplina pela "alfabetização do olhar" chave para que o futuro seja promissor.

Ao longo de toda a pesquisa, apontamos para um novo caminho. $\mathrm{Na}$ verdade, um caminho centrado na observação e no olhar atento para vencer os obstáculos da aprendizagem. A tradição oral assumida por professores de diferentes áreas, hoje é totalmente ultrapassada. É necessário urgentemente que a escola assim como outras instituições, derrube as barreiras da cultura letrada e abra as portas para receber a sociedade de linguagens múltiplas. 
É um longo caminho, que ora pode ser uma larga estrada, ora pequenas veredas, porém é necessário dar o primeiro passo e trilhá-lo de modo a facilitar o processo de ensinoaprendizagem. Afinal, esse é o grande desafio dos educadores na atualidade. Nesse contexto e amparada na leitura de imagem como instrumento facilitador da aprendizagem, a Geografia passa a figurar como a ciência capaz de transformar/revolucionar o processo educacional, à medida que contribui para transformar o espaço num local ambientalmente mais justo e igualitário.

No entanto, para se alcançar uma sociedade acessível a todos, independentes de cor, raça, religião, condição física e social, é de suma importância que as informações cheguem a todos e não somente aqueles culturalmente mais privilegiados. Resgatar o interesse pela Geografia deve ser o grande objetivo dos professores da disciplina na atualidade e esse resgate virá a partir do momento em que o aluno perceber que os conteúdos vivenciados tem significado para sua vida. E isso só será possível quando forem utilizadas linguagens com as quais eles se identifiquem. A instituição escolar deve contribuir para a prática cidadã e não deve de forma alguma acreditar que isso só será possível de uma única maneira. A escola deve prezar pela autonomia intelectual do aluno independente da linguagem utilizada ser verbal, escrita ou visual amplamente empregada na atualidade. Olhar, olhar de novo, selecionar, questionar e comparar ajudará o jovem a construir seus conceitos tornando-se agentes de sua aprendizagem, constituindo assim o primeiro passo para a construção de uma EDUCAÇÃO DE QUALIDADE.

\section{Referências bibliográficas}

BIANCO-FELDMAN, Bela; LEITE, Miriam L. Moreira (Orgs). Desafios da imagem: fotografia, iconografia e vídeo nas ciências sociais. Campinas: Papirus, 1998.

BRASIL. Ciências Humanas e suas Tecnologias / Secretaria de Educação Básica. - Brasília: Ministério da Educação, Secretaria de Educação Básica, v. 3. 133 p. (Orientações curriculares para o ensino médio), 2006.

CALLAI, Helena Copetti. Estudar o lugar para compreender o mundo. In: CASTROGIOVANNI, Antonio Carlos (Org.). Ensino de Geografia: práticas e textualizações no cotidiano. 7. ed. Porto Alegre: Mediação, 2009.

COELHO, Marcos Amorim; TERRA, Lígia. Geografia do Brasil: Espaço natural, territorial e socioeconômico brasileiro. 7. ed. São Paulo: Moderna, 2002.

COSTA, Cristina. Educação, imagem e mídias. São Paulo: Cortez, 2005.

DUARTE, Rosália. Imagem, linguagem visual e conhecimento escolar. In: SILVA, Aida Maria Monteiro; MACEDO, Martins Teixeira; MELO, Márcia Maria de Oliveira; BARBOSA, Maria Lúcia de Figueiredo (Orgs). Políticas educacionais, tecnologias e formação de educador: Repercussões sobre a didática e as práticas de ensino. Recife: Bagaço, 2006.

FLUSSER, Vilém. Ensaio sobre a Fotografia: para uma filosofia da técnica, mediações,1998.

FREIRE, Paulo. A importância do ato de ler: em três artigos que se completam. 23. ed. São Paulo: Cortez, 1989.

GINZBURG, Carlo. O queijo e os vermes. São Paulo: Companhia das Letras, 1987.

Geografia Ensino \& Pesquisa, v. 17, n. 2 p. $88-106$, maio./ago. 2013

Girão, O.; Lima, S. R. 
MARTINS, José de Souza. Sociologia da Fotografia e da Imagem. São Paulo: Contexto, 2009.

MARTINS, Walda de Andrade (coord.). Lendo e formando leitores: Orientações para o trabalho com a literatura infantil: circuito campeão. $2^{\circ}$ volume. Série inicial, primeira e segunda série. São Paulo: Global, 2009.

MOREIRA, João Carlos e SENE, Eustáquio de. Geografia. Vol. 2 - Ensino Médio. São Paulo: Scipione, 2005.

O FIM do Bucolismo de Casa Forte. Diário de Pernambuco, Recife, 17 jan. Caderno C, p. 4. 2010.

PONTUSCHKA, Nídia Nacib; PAGANELLI, Tomoko Iyda; CACETE, Núria Hanglei. Para ensinar e aprender Geografia. São Paulo: Cortez, 2007.

PONTUSCHKA, Nídia Nacib; OLIVEIRA, Ariovaldo Umbelino de. Geografia em Perspectiva. 3. ed. São Paulo: Contexto, 2009.

REgO, Nelson; CASTROGIOVANNI, A. Carlos; KAERCHER, Nestor André. Geografia Práticas Pedagógicas para o Ensino Médio. Porto Alegre: Artmed, 2007.

SAMAIN, Etienne. Questões heurísticas em torno do uso das imagens nas Ciências Sociais. In: FELDMAN-BIANCO, Bela e LEITE, Miriam L. Moreira. Desafios da Imagem: fotografia, iconografia e vídeo nas ciências sociais. Campinas: Parpirus, 1998.

\section{Correspondência:}

Osvaldo Girão - Rua Catulo da Paixão Cearense, 1021. CEP 53.050-090 Olinda-PE

E-mail: osgirao@gmail.com

Recebido em 16 de abril de 2012.

Revisado pelo autor em 12 abril de 2013.

Aceito para publicação em 13 de maio de 2013.

Geografia Ensino \& Pesquisa, v. 17 n. 2 p. $88-106$, maio./ago. 2013

O ensino de geografia versus leitura de imagens: resgate e valorização da disciplina pela "alfabetização do olhar" 